\title{
Clitoral Carcinoma
}

National Cancer Institute

\section{Source}

National Cancer Institute. Clitoral Carcinoma. NCI Thesaurus. Code C9362.

A carcinoma that arises from the clitoris. 